\title{
EVALUATION THE PHYSIOLOGICAL QUALITY OF Brachiaria brizantha cv. BRS 'Piatã' SEEDS
}

\author{
AVALIAÇÃO DA QUALIDADE FISOLÓGICA DE SEMENTES DE Brachiaria \\ brizantha $c v$. BRS 'Piatã'
}

\section{Givanildo Zildo da SILVA ${ }^{1}$; Cibele Chalita MARTINS²; José de Oliveira CRUZ Tatiane Sanches JEROMINI ${ }^{3}$; Riselane de Lucena Alcântara BRUNO ${ }^{4}$}

1. Engenheiro Agrônomo, Doutorando, Universidade Estadual Paulista - UNESP, Faculdade de Ciências Agrárias e Veterinárias, Jaboticabal, SP, Brasil. givanildozildo@ hotmail.com; 2. Engenheira Agrônoma, Professora Livre-Docente, Faculdade de Ciências Agrárias e Veterinárias - UNESP, Jaboticabal, SP, Brasil; 3. Engenheiro Agrônomo(a), Mestrando(a), Faculdade de Ciências Agrárias e Veterinárias - UNESP, Jaboticabal, SP, Brasil; 4. Engenheira Agrônoma, Professora Doutora em Agronomia, Universidade Federal da Paraíba, Areia, PB, Brasil.

\begin{abstract}
In a quality control program, seed vigor evaluation is of fundamental importance for the success of the program. The objective of this project was to evaluate the efficiency of several vigor tests to evaluate the physiological quality of Brachiaria brizantha cv. 'BRS Piatã' seed lots and to preview seedling emergence in the field. Ten grass seed lots of the $B$. brizantha $\mathrm{cv}$. 'BRS Piatã' were evaluated by the following tests: germination, first count of germination, accelerated aging $\left(43^{\circ} \mathrm{C} / 48\right.$ hours), cold test (seeds rolled in paper towel), seed water content before and after accelerated aging, electrical conductivity $\left(50\right.$ and $75 \mathrm{~mL}, 25^{\circ} \mathrm{C}$ and readings made $2,4,6,8$, and 24 hours after beginning the test), speed of germination index, and seedling emergence in sand substratum in the laboratory $\left(26 \pm 3{ }^{\circ} \mathrm{C}\right)$ and daily seedling counts between the 7th and the 21th day after sowing. The treatment replications were distributed in the laboratory according to a completely random design with four replications. Seedling emergence in the field data were analyzed according to a randomized complete block design. Treatment means were compared by the Scott Knott test, at the 5\% level of probability. The tests for germination and first germination count, seedling emergence and first emergence count in the sand, and accelerated aging are useful to assess the vigor of seed batches of the piatã grass, and provide similar evidence to the seedling emergence in the field.
\end{abstract}

KEYWORDS: Forage grasses. Pasture. Vigor tests. Seedling emergence in the field.

\section{INTRODUCTION}

Brazil is the largest world producer, consumer and exporter of forage grass seeds. Among the commercialized species, Brachiaria brizantha is the most important (PEREIRA et al., 2011). The 'BRS Piatã' cultivar started to be distributed among farmers in 2007 by EMBRAPA (Brazilian Agency for Agricultural Investigation) since it displays superior qualities in comparison with cultivar 'Marandu', which was then the prevailing cultivar in pasture areas (EMBRAPA CNPGC, 2015). In comparison with that cultivar, 'Piatã' forage is of better quality, produces larger amounts of leaves and thin culms, easily reaches the state of hay, produces precociously, and presents tolerance to soil humidity (MONTAGNER et al., 2013).

As a consequence of the national seed market development and also to meet an ever growing demand by the international market, forage seed companies have sought better laboratory tests to be used in quality control programs similar to those used in the cereal seeds industry (DIAS et al.,
2004; DIAS; ALVES, 2008; BATISTA; CERRITOS, 2014; TOMAZ et al., 2015).

The germination and vigor tests are used to select the best seed lots as to storage and field performance (GRZYBOWSKI et al., 2015; MARCOS FILHO, 2015). These are data which can be used in decision making processes as to the best moment to commercialize a seed lot, its best destination, its best position in the storage room, and even its selling price (NOGUEIRA et al., 2013; MARCOS FILHO, 2015).

Some tests were identified as the most efficient to rank seed lots of the most important crops such as the cold test for corn, barley, rice and sorghum (MARCOS FILHO, 2015), the electrical conductivity test for soybean and pea (ISTA, 2006; MACHADO et al., 2011), and the accelerated aging test for corn, oats and wheat (MARCOS FILHO, 2015).

The electrical conductivity test was efficient to differentiate temperate grass seed lots, such as black oat and triticale (STEINER et al., 2011; NOGUEIRA et al., 2013). The results were quickly obtained since the tests demanded between 16 and 20 hours for black oat seeds (NOGUEIRA et al., 
2013) and 48 hours for triticale (STEINER et al., 2011). The cold test without soil and that of the accelerated aging test at $41{ }^{\circ} \mathrm{C}$ for 96 hours were efficient in classifying sorghum lots as to vigor and respective seedling emergence in the field performance (SOARES et al., 2010).

An investigated test to evaluate the vigor of temperate forage grass seed was the accelerated aging with water at $41{ }^{\circ} \mathrm{C}$ for periods of 24 and 48 hours for millet and Lolium multiflorum seeds (GARCIA; MENEZES, 1999). To evaluate the storage potential of three seed lots of $B$. brizantha cv. 'Marandu', a tropical forage species, Dias et al. (2004) submitted the seeds to a temperature of 43 ${ }^{\circ} \mathrm{C}$ for 48 hours before testing them.

Thus, the objective of this project was to verify the efficiency of different vigor tests to evaluate the physiological quality of $B$. brizantha cv. 'BRS Piatã' seed lots and to predict seedling emergence in the field.

\section{MATERIAL AND METHODS}

The research work was conducted at the Seed Analyses Laboratory of the Paulista State University (UNESP), in Jaboticabal, state of São Paulo, Brazil. Ten B. brizantha seed lots were evaluated. Five of those lots were produced in the municipalities of Tupaciguara (two lots), Unai (two lots) and Uruana de Minas, in the state of Minas Gerais and five lots in the municipality of Santo Anastácio, state of São Paulo, both states in Brazil. All the lots were sampled at their reception at the seed company. After reception, the lots were homogenized and cleaned so as to get the pure seed fraction. These seeds were submitted to the following tests:

Germination - this test was based on four 100 seed samples which were sown on top of two filter paper sheets which were previously wet with an amount of distilled water equal to 2.5 times the weight of the dry substratum. These sheets were placed inside transparent plastic $11.0 \times 11.0 \times 3.5$ $\mathrm{cm}$ large boxes, kept at temperatures between 20 and $35{ }^{\circ} \mathrm{C}$ with normal seedlings being counted 7 and 21 days after sowing (BRASIL, 2009).

The firm, non-germinated seeds remaining at the end of the test were submitted to the tetrazolium test to differentiate dead from dormant seeds. These seeds were longitudinally sectioned, through the embryo, and one of the resulting halves was immersed in a $0.1 \%$ tetrazolium solution at a temperature of $37{ }^{\circ} \mathrm{C}$ for three hours in the dark (DIAS; ALVES, 2008). Following that period, the seeds were washed in distilled water and the reading was immediately made and the seeds classified in viable (dormant) and non-viable (dead) (BRASIL, 2009).

First count of germination - this evaluation was simultaneous with the preceding test. The percentage of normal seedlings at the first count ( 7 days after test beginning) was considered as an indicator of seed vigor (BRASIL, 2009).

Accelerated aging - a total of 260 seeds was spread on top of a screen inside transparent plastic $11.0 \times 11.0 \times 3.5 \mathrm{~cm}$ large boxes to the bottom of which $40 \mathrm{~mL}$ of water (100\% of relative humidity) were added. These boxes were kept under a temperature of $43{ }^{\circ} \mathrm{C}$ for 48 hours (DIAS et al., 2004). After this the seeds had their germination evaluated by counting the number of normal seedlings 7 days after test beginning.

Seed water content - it was determined before the germination test and after accelerated aging. The procedure consisted in submitting three $0.5 \mathrm{~g}$ seed samples to temperatures of $105 \pm 3{ }^{\circ} \mathrm{C}$ for 24 hours (BRASIL, 2009) followed by weighing the dry samples.

Cold test - four 50 seed samples in paper towel were wet with distilled water (the amount of water was that equal to 2.5 times the weight of the substratum) and then kept at the temperature of 10 ${ }^{\circ} \mathrm{C}$ for seven days. After that period the rolled paper towels were transferred to a germinator kept at 20 $35{ }^{\circ} \mathrm{C}$ for seven days. At the end, the number of normal seedlings was counted (MARCOS FILHO, 2005).

Electrical conductivity - four $1.5 \mathrm{~mL}$ of seeds per lot (approximately 140 seeds), quantified with the help of a tube of the Eppendorf type and weighed in a $0.001 \mathrm{~g}$ precision scale were used. The expressing of seeds in volume, instead of the traditional use of numbers, viewed to make more practical the test for small seeds for routine analyses in the company laboratory. The seeds were placed in plastic cups with two volumes of deionized water, 50 and $75 \mathrm{~mL}$, at $25^{\circ} \mathrm{C}$ and the readings were made after $2,4,6,8$, and 24 hours in a conductivimeter and the results were expressed in $\mu \mathrm{S} . \mathrm{cm}^{-1} \cdot \mathrm{g}^{-1}$.

Seedling growth - four 20 seed subsamples per lot were sown on top of parallel lines drawn on the upper third of the sheet which had been previously moistened with an amount of water equivalent to 2.5 times $(\mathrm{g})$ the paper weight. The paper towel rolls were placed standing on one end inside plastic bags to reduce dehydration. The test was conducted at the temperature of $25^{\circ} \mathrm{C}$ and was interrupted seven days after sowing. Then, the seedlings had their root and aerial part length 
measured with the help of a common rule, graduated in mm (PEREIRA et al., 2009).

Seedling emergence in sand - fifty seeds per replication were sown in sand in plastic boxes $(22.0$ $\mathrm{x} 15.0 \times 5.0 \mathrm{~cm}$ ) which were kept at the constant temperature of $26 \pm 3{ }^{\circ} \mathrm{C}$; the number of normal seedlings was determined 21 days after sowing. At the same time the first count of germination value was determined on the $7^{\text {th }}$ days after sowing and the speed of emergence index was determined by means of daily counts of normal seedlings. Speed of emergence index was calculated with the help of Maguire's (1962) formula.

Seedling emergence in the field - seed samples of 50 seeds each were sown in seedbeds in $1.5 \mathrm{~m}$ long rows in a spacing of $0.2 \mathrm{~m}$ between lines and at a depth of two centimeters. Seedling counts were daily made up to 21 days after sowing, with results being expressed in percentage (OLIVEIRA et al., 2014). During the mentioned period, daily data of temperature, relative humidity, rain precipitation, and insolation were registered.

The treatment replications were distributed according to a completely random design with the exception of the seedling emergence in the field test in which the distribution was in accordance with a randomized complete block design. The data were first submitted to the analysis of variance and the means compared by the Scott Knott test at the 5\% level of probability. The analysis of principal components was procedure in the $\mathrm{R}$ program $(\mathrm{R}$ CORE TEAM, 2016).

\section{RESULTS AND DISCUSSION}

Seed water content values are shown in Table 1 . These values varied between 10.8 to $11.3 \%$ and between 20.0 and $22.6 \%$ before and after seed ageing, respectively. These values are in accordance to those recommended for the standardization of vigor tests (MARCOS FILHO, 2005).

Based on the tetrazolium test results it was verified that most of the non-germinated seeds were dead and not dormant. The percentage of dormant seeds was low - between 0 and $2 \%$ - and the F test detected no significant difference between these values (data not shown in the tables).

Table 1. Seed water content before (WB) and after (WA) accelerated aging, seedling emergence in the field (SEF), emergence (ES) and first count of germination in sand (FCS), germination (G), first count of germination (FCG), cold test (CT), accelerated aging (AA) and seedling growth as measured by the main root and aerial part growth of 10 lots of Brachiaria brizantha cv. 'BRS Piatã' seeds.

\begin{tabular}{|c|c|c|c|c|c|c|c|c|c|c|c|}
\hline \multirow{2}{*}{ Lots } & \multirow{2}{*}{ TA } & \multirow{2}{*}{ TAE } & \multirow{2}{*}{ SEF } & \multicolumn{2}{|c|}{$\begin{array}{c}\text { Caixas com areia } \\
\text { no laboratório }\end{array}$} & \multirow{2}{*}{$\mathrm{G}$} & \multirow{2}{*}{ FCG } & \multirow{2}{*}{ CT } & \multirow{2}{*}{ AA } & \multicolumn{2}{|c|}{ Growth } \\
\hline & & & & ES & FCS & & & & & Root & $\begin{array}{c}\text { Aerial } \\
\text { part }\end{array}$ \\
\hline & \multicolumn{9}{|c|}{ 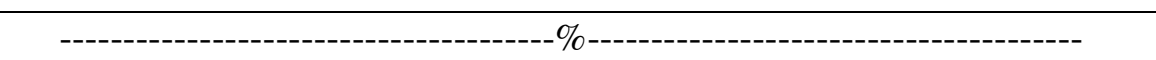 } & \multicolumn{2}{|c|}{ 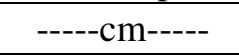 } \\
\hline 1 & 11.1 & 20.8 & $74 \mathrm{a}$ & $86 \mathrm{a}$ & $72 \mathrm{a}$ & $90 \mathrm{a}$ & $83 \mathrm{a}$ & $69 \mathrm{a}$ & $79 \mathrm{a}$ & $7.8 \mathrm{~b}$ & $7.6 \mathrm{a}$ \\
\hline 2 & 11.3 & 22.6 & $73 \mathrm{a}$ & $85 \mathrm{a}$ & $78 \mathrm{a}$ & $88 \mathrm{a}$ & $83 \mathrm{a}$ & $67 \mathrm{a}$ & $79 a$ & $8.2 \mathrm{~b}$ & $5.6 \mathrm{c}$ \\
\hline 3 & 10.8 & 21.2 & $76 a$ & $78 \mathrm{a}$ & $69 \mathrm{a}$ & $89 \mathrm{a}$ & $88 \mathrm{a}$ & $66 \mathrm{a}$ & $67 \mathrm{~b}$ & $7.3 \mathrm{c}$ & $5.6 \mathrm{c}$ \\
\hline 4 & 11.1 & 20.9 & $66 \mathrm{a}$ & $85 \mathrm{a}$ & $74 \mathrm{a}$ & $85 \mathrm{a}$ & $76 \mathrm{~b}$ & $62 \mathrm{a}$ & $72 \mathrm{a}$ & $8.9 \mathrm{a}$ & $7.8 \mathrm{a}$ \\
\hline 5 & 10.9 & 21.4 & $68 \mathrm{a}$ & $81 \mathrm{a}$ & $71 \mathrm{a}$ & $84 \mathrm{a}$ & $79 \mathrm{~b}$ & $72 \mathrm{a}$ & $71 \mathrm{a}$ & $7.2 \mathrm{c}$ & $6.9 \mathrm{~b}$ \\
\hline 6 & 11.2 & 21.6 & $71 \mathrm{a}$ & $81 \mathrm{a}$ & $78 \mathrm{a}$ & $75 \mathrm{~b}$ & $74 \mathrm{~b}$ & $49 \mathrm{~b}$ & $67 \mathrm{~b}$ & $9.1 \mathrm{a}$ & $7.2 \mathrm{~b}$ \\
\hline 7 & 10.8 & 21.5 & $57 \mathrm{~b}$ & $67 \mathrm{~b}$ & $56 \mathrm{~b}$ & $87 \mathrm{a}$ & $77 \mathrm{~b}$ & $66 \mathrm{a}$ & $75 \mathrm{a}$ & $9.4 \mathrm{a}$ & $8.3 \mathrm{a}$ \\
\hline 8 & 11.3 & 22.0 & $54 \mathrm{~b}$ & $61 \mathrm{~b}$ & $50 \mathrm{~b}$ & $77 \mathrm{~b}$ & $75 \mathrm{~b}$ & $67 \mathrm{a}$ & $42 \mathrm{c}$ & $7.8 \mathrm{~b}$ & $4.8 \mathrm{c}$ \\
\hline 9 & 10.8 & 20.0 & $53 \mathrm{~b}$ & $72 \mathrm{~b}$ & $57 \mathrm{~b}$ & $78 \mathrm{~b}$ & $73 \mathrm{~b}$ & $59 \mathrm{~b}$ & $65 \mathrm{~b}$ & $6.5 \mathrm{c}$ & $6.5 \mathrm{~b}$ \\
\hline 10 & 11.0 & 22.0 & $59 \mathrm{~b}$ & $72 \mathrm{~b}$ & $57 \mathrm{~b}$ & $80 \mathrm{~b}$ & $74 \mathrm{~b}$ & $53 \mathrm{~b}$ & $63 \mathrm{~b}$ & $5.6 \mathrm{~d}$ & $5.3 \mathrm{c}$ \\
\hline $\mathrm{F}$ & & & $3.09^{* *}$ & $4.11^{* *}$ & $5.40^{* *}$ & $6.40^{* *}$ & $3.94^{* *}$ & $4.75^{* *}$ & $16.74^{* *}$ & $9.81^{* *}$ & $14.25^{* *}$ \\
\hline $\mathrm{CV}(\%)$ & & & 16.74 & 10.88 & 13.28 & 5.26 & 6.41 & 10.64 & 7.86 & 9.64 & 9.59 \\
\hline
\end{tabular}

** Significant at the $1 \%$ level of probability by the $\mathrm{F}$ test. Means followed by the same letter are not statistically different according to the Scott-Knott test at the $5 \%$ level of probability.

The low and similar dormancy values are an indication that the vigor tests results were not affected by the phenomenon. Although $B$. brizantha seeds are sometimes dormant (BRASIL, 2009) this has not been observed nowadays in commercial lots of seeds of this species, this being probably due to the fact that the harvested seeds are those which have naturally fallen from the plant and are swept to 
be collected, or, in other words, only the physiologically mature seeds are harvested, that is, the seeds which have had the time to complete the maturation process (MASCHIETTO et al., 2003; GASPAR-OLIVEIRA et al., 2008; TOMAZ et al., 2015).

Seedling emergence in the field data were used as a reference for the selection of the vigor tests. During that phase, the mean temperature was of $23 \pm 5^{\circ} \mathrm{C}$ and the mean relative humidity of 76.9 $\pm 25 \%$. Rain precipitation was of $86.4 \mathrm{~mm}$ during the seven-day period and insolation of 234.5 hours (UNESP Meteorological Station - Jaboticabal, SP). Based on the seedling emergence in the field results the lots were classified as to field performance in decreasing order of vigor from 1 to 10 which were grouped in two classes of vigor: high (lots 1 to 6 ) and low (lots 7 to 10) (Table 1).

Two of the evaluated tests detached themselves from the others - the first count of germination and the seedling emergence tests, both carried out in the laboratory and having sand as a substratum. These tests made possible the ranking of the lots in a way similar to that observed in the field. So, these tests may be considered as efficient to be part of seed quality control programs for the production of 'Piatã' grass seeds. The speed of emergence index test, although conducted with the same substratum and in the same environmental conditions of the promising tests, was not capable of detecting significant differences among the lots. Thus, the data related to this parameter were not shown.

Similar results were reported for sorghum (SOARES et al., 2010), rice (TUNES et al., 2012), and wheat (MERTZ et al., 2012) seeds - seedling emergence in protected environment was an efficient test to select lots of high physiological potential and field performance.

All the lots used in this experiment germinated more than $60 \%$ (Table 1) this being the minimum required by legislation for the commercialization of braquiaria grass seeds (BRASIL, 2008). This is a low value if compared to the minima established for cereal crops such as corn, soybean, and rice, i.e., between 80 and $85 \%$ (BRASIL, 2013). Therefore, differently from the reported in other studies (VANZOLINI et al., 2007; COIMBRA et al., 2009; TUNES et al., 2012; GRZYBOWSKI et al., 2015) with seeds of the same species of this work, the germination distribution values were situated in a larger range, that is, from 77 to $90 \%$. This is thought to be an indication that the germination test was efficient to differentiate the lots as to physiological potential.
The germination test classified the lots in two vigor groups: high (lots 1, 2, 3, 4, 5, and 7) and low (lots 6, 8, 9, and 10). So, this test was less efficient than that of the first count of germination and that of seedling emergence in sand in the laboratory, since, when compared to seedling emergence in the field, it showed an accuracy of $80 \%$ - its mistakes happened when it classified lot 6 as of low vigor and lot 5 as of high vigor.

But the germination test could be adopted in conjunction with first count of germination and seedling emergence in sand in laboratory to evaluate the quality of 'Piatã' grass seeds since, according to Marcos Filho (2015), the distinction between seed lots demands a certain number of vigor tests - at least three of them.

Similarly, to the germination test, the first count of germination and the cold tests classified the seed lots in two groups. But these tests were of less efficiency since only $70 \%$ of the classification they provided was coincident with the performance shown by the lots in the field. The first count of germination and the cold tests classified lots 4 to 10 and $6,9,10$, respectively, as of low vigor and the others as of high vigor.

The first count of germination is an indirect measure of speed of germination which is a desirable characteristic for the establishment of pastures (PARIZ et al., 2010). The cold test is routinely used in quality control programs for the production of corn, barley, rice and sorghum seeds (MARCOS FILHO, 2015).

The results of the other tests [accelerated aging, seedling growth, and electrical conductivity (Tables 1 and 2)] were conflicting and unreliable their classification of the lots as to vigor did not coincide with the seedling emergence in the field results, which is the reference for vigor tests.

The inefficiency of the electrical conductivity test is probably related to the seed harvesting method (seeds after naturally falling onto the ground are swept and gathered with the help of a broom) (MASCHIETTO et al., 2003) - the contact between the seeds and materials such as soil, fertilizers residues, and organic matter is likely to impregnate them with substances capable of interfering in the electrical conductivity test results.

Cluster analysis of the tests revealed the existence of four groups of batches that presented different seed quality (Figure 1). The Euclidian distance used for this purpose was 6.4. To explain data variability in the principal 
component analysis of the $10 \mathrm{~B}$. brizantha lots, two components were used with a total variance of $53.14 \%$ and $21.09 \%$. The sum of these values was $73.23 \%$ of the accumulated variance (Figure $1 \mathrm{~B}$ ).

Table 2. Electrical conductivity values of Brachiaria brizantha cv. 'BRS Piatã' seeds after imbibition in water volumes of 50 and $75 \mathrm{~mL}$ for $2,4,6,8$, and 24 hours

\begin{tabular}{|c|c|c|c|c|c|c|c|c|c|c|}
\hline \multirow{3}{*}{ Lots } & \multicolumn{10}{|c|}{ Electrical conductivity $\left(\mu \mathrm{S} \mathrm{cm}^{-1} \mathrm{~g}^{-1}\right)$} \\
\hline & \multicolumn{5}{|c|}{$50 \mathrm{~mL}$} & \multicolumn{5}{|c|}{$75 \mathrm{~mL}$} \\
\hline & $2 \mathrm{~h}$ & $4 \mathrm{~h}$ & $6 \mathrm{~h}$ & $8 \mathrm{~h}$ & $24 \mathrm{~h}$ & $2 \mathrm{~h}$ & $4 \mathrm{~h}$ & $6 \mathrm{~h}$ & $8 \mathrm{~h}$ & $24 \mathrm{~h}$ \\
\hline 1 & $40.5 \mathrm{~d}$ & $47.9 \mathrm{~d}$ & $53.1 \mathrm{~d}$ & $58.5 \mathrm{~d}$ & $84.9 \mathrm{~d}$ & $23.9 \mathrm{c}$ & $28.9 \mathrm{~d}$ & $32.1 \mathrm{c}$ & $35.4 \mathrm{c}$ & $49.5 \mathrm{c}$ \\
\hline 2 & $31.5 \mathrm{c}$ & $39.3 \mathrm{c}$ & $45.8 \mathrm{c}$ & $50.5 \mathrm{c}$ & $66.7 \mathrm{c}$ & $23.0 \mathrm{c}$ & $27.4 \mathrm{~d}$ & $34.1 \mathrm{c}$ & $36.8 \mathrm{c}$ & $47.6 \mathrm{c}$ \\
\hline 3 & $24.1 \mathrm{~b}$ & $28.9 \mathrm{~b}$ & $34.2 \mathrm{~b}$ & $37.7 \mathrm{~b}$ & $53.1 \mathrm{~b}$ & $18.3 \mathrm{~b}$ & $23.8 \mathrm{c}$ & $26.4 \mathrm{~b}$ & $30.0 \mathrm{~b}$ & $40.1 \mathrm{c}$ \\
\hline 4 & $19.3 \mathrm{a}$ & $23.6 \mathrm{a}$ & $26.6 \mathrm{a}$ & $29.1 \mathrm{a}$ & $38.0 \mathrm{a}$ & $13.3 \mathrm{a}$ & $16.0 \mathrm{a}$ & $18.2 \mathrm{a}$ & $19.9 \mathrm{a}$ & $25.4 \mathrm{a}$ \\
\hline 5 & $24.4 \mathrm{~b}$ & $27.3 \mathrm{a}$ & $30.7 \mathrm{a}$ & $33.6 \mathrm{a}$ & $45.0 \mathrm{a}$ & $14.1 \mathrm{a}$ & $17.1 \mathrm{a}$ & $19.5 \mathrm{a}$ & $21.3 \mathrm{a}$ & $29.0 \mathrm{a}$ \\
\hline 6 & $28.3 \mathrm{c}$ & $35.8 \mathrm{c}$ & $41.8 \mathrm{c}$ & $46.8 \mathrm{c}$ & $63.7 \mathrm{c}$ & $19.2 \mathrm{~b}$ & $25.4 \mathrm{c}$ & $29.5 \mathrm{c}$ & $33.8 \mathrm{c}$ & $45.8 \mathrm{c}$ \\
\hline 7 & $25.6 \mathrm{~b}$ & $33.2 \mathrm{~b}$ & $37.7 \mathrm{~b}$ & $41.8 \mathrm{~b}$ & $53.6 \mathrm{~b}$ & $17.0 \mathrm{a}$ & $21.6 \mathrm{~b}$ & $26.0 \mathrm{~b}$ & $27.3 \mathrm{~b}$ & $33.9 \mathrm{~b}$ \\
\hline 8 & $23.3 \mathrm{~b}$ & $30.7 \mathrm{~b}$ & $35.8 \mathrm{~b}$ & $40.0 \mathrm{~b}$ & $51.6 \mathrm{~b}$ & $15.6 \mathrm{a}$ & $20.5 \mathrm{~b}$ & $24.1 \mathrm{~b}$ & $26.7 \mathrm{~b}$ & $34.3 \mathrm{~b}$ \\
\hline 9 & $29.1 \mathrm{c}$ & $34.8 \mathrm{c}$ & $38.1 \mathrm{~b}$ & $41.8 \mathrm{~b}$ & $59.7 \mathrm{c}$ & $19.5 \mathrm{~b}$ & $23.2 \mathrm{c}$ & $25.7 \mathrm{~b}$ & $27.7 \mathrm{~b}$ & $37.3 \mathrm{~b}$ \\
\hline 10 & $29.6 \mathrm{c}$ & $35.5 \mathrm{c}$ & $40.2 \mathrm{c}$ & $43.4 \mathrm{~b}$ & $59.7 \mathrm{c}$ & $19.1 \mathrm{~b}$ & $23.2 \mathrm{c}$ & $25.7 \mathrm{~b}$ & $28.5 \mathrm{~b}$ & $37.0 \mathrm{~b}$ \\
\hline $\bar{F}$ & $23.76^{* *}$ & $22.17^{* *}$ & $18.53^{* *}$ & $20.23^{* *}$ & $17.75^{* *}$ & $9.97^{* * *}$ & $6.54^{* *}$ & $8.05^{* *}$ & $8.43^{* *}$ & $7.85^{* *}$ \\
\hline $\mathrm{CV}(\%)$ & 9.64 & 9.59 & 10.17 & 9.83 & 11.84 & 13.46 & 15.78 & 14.95 & 14.83 & 16.57 \\
\hline
\end{tabular}

** Significant at the $1 \%$ level of probability by the F test. Means followed by the same letter are not statistically different according to the Scott-Knott test at the $5 \%$ level of probability.

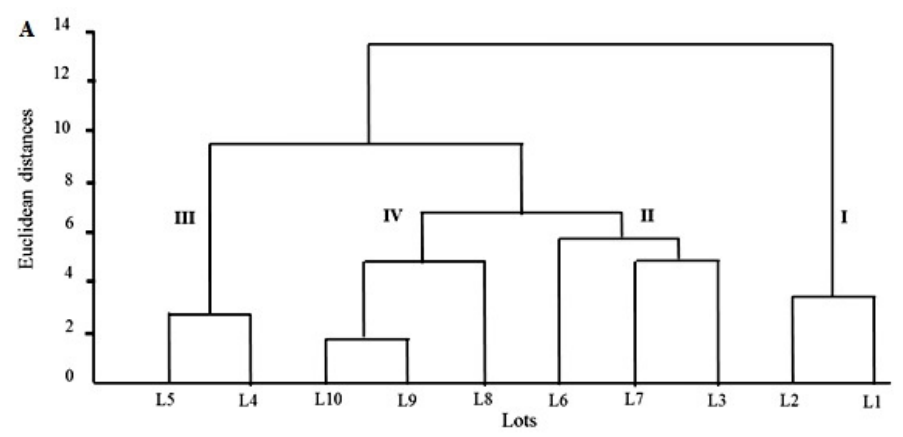

B

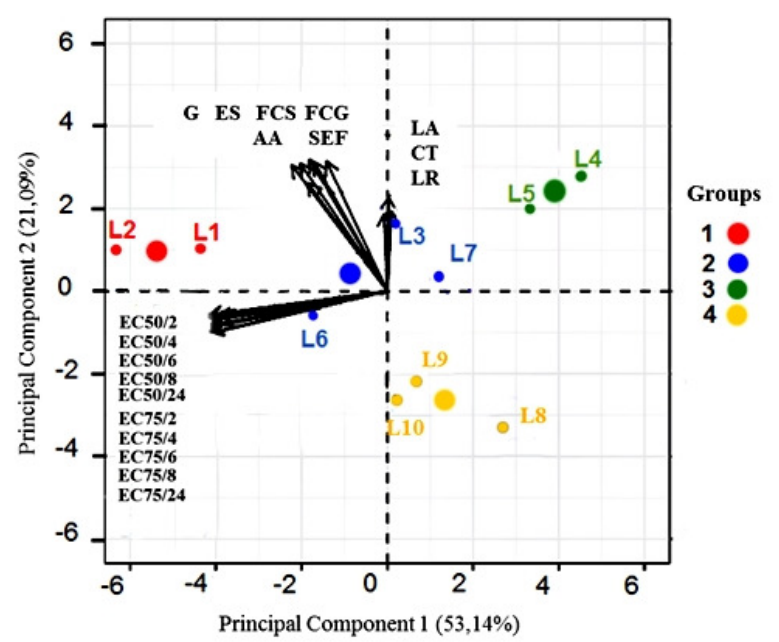

Figure 1. Dendrogram resulting from the hierarchical clustering analysis with group formation (A) and circle of eigenvectors and dispersion plan (B) obtained with principal component analysis based on seedling emergence in the field (SEF), germination (G), first count os germination (FCG), emergence (ES), first count of germination in sand (FCS), accelerated aging (AA), could test (CT), aerial part (AL) and root (AR) length of seedlings and electrical conductivity in 50 and $75 \mathrm{~mL}$, at 2 , 4, 6,8 and 24 hours of seed imbibition of 10 batches of Brachiaria brizantha cv. BRS Piatã. 
Figure 1B shows the large correlations observed between the variables seedling emergence in the field, seedling emergence and first emergence count in the sand, germination and first germination count, and accelerated aging indicated the acute angles formed between the arrows describing these parameters. In contrast, the variables electrical conductivity measured at the different imbibition volumes and time points, cold test, and seedling root and shoot length did not show large correlations with seedling emergence in the field, since the arrows formed close to $90^{\circ}$ angles with respect to the latter parameter.

According to Hongyu et al. (2015), the discriminatory power of variables within each principal component is measured by correlation. Therefore, based on the values depicted in Table 3, it can be inferred that the variables seedling emergence in the field (0.71), emergence in the sand $(0.74)$, first count in the sand $(0.74)$, germination (0.71), first germination count (0.60), and accelerated aging (0.70) correlated with the principal component 2 . These correlations allowed the distinction of group 1, located at the upper part of Figure 1B

For the electrical conductivity test in seeds obtained at different imbibition time points and volumes, negative correlations were found between -0.91 and -0.97 and the principal component 1 (Table 3 ).

Table 3. Correlation between each principal component and the evalution of the physiological performance of 10 seed batches of Brachiaria brizantha cv. BRS Piatã.

\begin{tabular}{llll}
\hline \multirow{2}{*}{ Variables } & \multicolumn{2}{l}{ Principal component (PC) } \\
\cline { 2 - 3 } & & PC1 & PC2 \\
\hline Seedling emergence in the fieldo & $-0,52$ & 0,71 \\
Seedling emergence in sand & $-0,42$ & 0,74 \\
First count of germination in sand & $-0,39$ & 0,74 \\
Germination & & $-0,34$ & 0,71 \\
First count of germination & & $-0,44$ & 0,60 \\
Cold test & 0,01 & 0,44 \\
Accelered aging & & $-0,48$ & 0,70 \\
Root length & & 0,01 & 0,45 \\
Arial part length & 0,01 & 0,52 \\
Electrical conductivity & EC $50 \mathrm{~mL} / 2 \mathrm{~h}$ & $-0,91$ & $-0,16$ \\
& EC $50 \mathrm{~mL} / 4 \mathrm{~h}$ & $-0,93$ & $-0,24$ \\
& EC $50 \mathrm{~mL} / 6 \mathrm{~h}$ & $-0,95$ & $-0,24$ \\
& EC $50 \mathrm{~mL} / 8 \mathrm{~h}$ & $-0,95$ & $-0,24$ \\
& EC $50 \mathrm{~mL} / 24 \mathrm{~h}$ & $-0,95$ & $-0,21$ \\
& EC $75 \mathrm{~mL} / 2 \mathrm{~h}$ & $-0,97$ & $-0,16$ \\
& EC $75 \mathrm{~mL} / 4 \mathrm{~h}$ & $-0,97$ & $-0,20$ \\
& EC $75 \mathrm{~mL} / 6 \mathrm{~h}$ & $-0,94$ & $-0,16$ \\
& EC $75 \mathrm{~mL} / 8 \mathrm{~h}$ & $-0,94$ & $-0,17$ \\
Total Variance $(\%)$ & EC $75 \mathrm{~mL} / 24 \mathrm{~h}$ & $-0,96$ & $-0,13$ \\
\hline Cumulative Variance $(\%)$ & & 10,09 & 4,01 \\
& & 53,14 & 21,09 \\
\hline
\end{tabular}

It is worth highlighting that the relevant tests for batch assessment in seed analysis laboratories, not also rank batches according to vigor, but must also provide results on the correlation with seedling emergence in the field (MARCOS FILHO, 2015). Therefore, based on the principal component analysis, the tests for germination and first germination count, seedling emergence and first emergence count in the sand, and accelerated aging can be identified as promising tools to assess seed batches of $B$. brizantha $\mathrm{cv}$. BRS
Piatã. These results confirm those observed when comparing the mean values shown in Table 1, but in a simpler and clearer way.

\section{CONCLUSION}

The tests for germination and first germination count, seedling emergence and first emergence count in the sand, and accelerated aging are useful to assess the vigor of seed batches of the 
piatã grass, and provide similar evidence to the seedling emergence in the field.

RESUMO: Dentro de um programa de controle de qualidade, a avaliação do vigor de sementes é fundamental e necessária para o sucesso da produção. O objetivo do presente trabalho foi verificar a eficiência de diferentes testes de vigor na avaliação da qualidade fisiológica de sementes de Brachiaria brizantha cv. BRS Piatã para a diferenciação dos lotes e previsão de emergência de plântulas em campo. Dez lotes de sementes de capim-piatã foram avaliados pelos seguintes testes: germinação, primeira contagem de germinação, envelhecimento acelerado $\left(43{ }^{\circ} \mathrm{C} / 48 \mathrm{~h}\right)$, teor de água antes e após o envelhecimento acelerado, teste de frio (em rolo de papel), condutividade elétrica $\left(50\right.$ e $75 \mathrm{~mL}, 25^{\circ} \mathrm{C}$ e leituras após $2,4,6,8$ e $24 \mathrm{~h}$ ), crescimento de plântulas (em rolo de papel, $25{ }^{\circ} \mathrm{C}$ e encerrado no sétimo dia), primeira contagem, índice de velocidade de emergência e porcentagem de emergência de plântulas em substrato areia no laboratório ( $26 \pm 3{ }^{\circ} \mathrm{C}$ e contabilizando-se a porcentagem de plântulas emersas diariamente dos sete aos 21 dias após a semeadura) e emergência de plântulas em campo (21 dias). Adotou-se o delineamento inteiramente casualizado com quatro repetições. A emergência de plântulas em campo foi analisada em blocos casualizados. As médias dos tratamentos foram comparadas pelo teste de Scott Knott, a 5\% de probabilidade. Os testes de germinação e primeira contagem de germinação, emergência e primeira contagem de emergência de plântulas em areia e o envelhecimento acelerado são eficientes na avaliação do vigor de lotes de sementes de capim-piatã, fornecendo informações semelhantes à emergência de plântulas em campo.

PALAVRAS-CHAVE: Gramíneas forrageiras. Pastagem. Testes de vigor. Emergência de plântulas em campo.

\section{REFERENCES}

BATISTA, M. N.; CERRITOS, G. R. Forrageiras: Visão do mercado na América Latina. In: Anuário ABRASEM. Pelotas: Editora Becker \& Peske, 2014, p. 23-27.

BRASIL. Ministério da Agricultura, Pecuária e Abastecimento. Regras para análise de sementes. Secretaria de Defesa Agropecuária. Brasília: MAPA/ACS, 2009. 395p.

BRASIL. Ministério da Agricultura, Pecuária e do Abastecimento Gabinete do Ministro. Instrução Normativa $\mathrm{n}^{\circ}$ 30, de 21 de maio de 2008. Publicado no Diário Oficial da União, Poder Executivo, 23 de maio de 2008, Seção 1, p. 45.

BRASIL. Ministério da Agricultura, Pecuária e do Abastecimento Gabinete do Ministro. Instrução Normativa $\mathrm{n}^{\circ}$ 45, de 17 de setembro de 2013. Publicado no Diário Oficial da União, Poder Executivo, 23 de maio de 2013, Seção 1, p. 16.

COIMBRA, R. A.; MARTINS, C. C.; TOMAZ, C. A.; NAKAGAWA, J. Testes de vigor utilizados na avaliação da qualidade fisiológica de lotes de sementes de milho-doce (sh2). Ciência Rural, Santa Maria, v. 39, n. 9, p. 2402-2408, 2009. https://doi.org/10.1590/S0103-84782009000900004

DIAS, D. C. F. S.; SANTOS, P. S.; ALVARENGA, E. M.; CECON, P. R.; ARAÚJO, E. F. Testes para monitorar a qualidade fisiológica de sementes de Brachiaria brizantha (A. Rich.) Stapf. durante o armazenamento. Revista Brasileira de Sementes, Londrina, v. 26, n. 2, p. 33-44, 2004. https://doi.org/10.1590/S0101-31222004000200006

DIAS, M. C. L. L. and ALVES, S. J. Avaliação da viabilidade de sementes de Brachiaria brizantha (Hochst. ex A. Rich) Stapf pelo teste de tetrazólio. Revista Brasileira de Sementes, Londrina, v. 30, n. 3, p. 145-151, 2008. https://doi.org/10.1590/S0101-31222008000300019

EMBRAPA. Capim Piatã. Available at: <https://www.embrapa.br/busca-de-produtos-processos-e-servicos//produto-servico/865/capim-brachiaria---brs-piata>. Accessed on: November, 15, 2015. 
GARCIA, D. C. and MENEZES, N. L. Teste de envelhecimento precoce para sementes de azevém, aveia preta e milheto. Ciência Rural, Santa Maria, v. 29, n. 2, p. 233-237, 1999. https://doi.org/10.1590/S010384781999000200008

GRZYBOWSKI, C. R. S.; VIEIRA, R. D.; PANOBIANCO, M. Testes de estresse na avaliação do vigor de sementes de milho. Revista Ciência Agronômica, Mossoró, v. 46, n. 3, p. 590-596, 2015. https://doi.org/10.5935/1806-6690.20150042

GASPAR-OLIVEIRA, C. M.; MARTINS, C. C.; NAKAGAWA, J.; CAVARIANI, C. Duração do teste de germinação de Brachiaria brizantha cv. 'Marandu' (Hochst. ex A. Rich.) Stapf. Revista Brasileira de Sementes, Londrina, v. 30, n. 3, p. 30-38, 2008. http://dx.doi.org/10.1590/S0101-31222008000300005

HONGYU, K. SANDANIELO, V. L. M.; OLIVEIRA JUNIOR, G. J. Análise de Componentes Principais: resumo teórico, aplicação e interpretação. Engineering and Science, v. 1, n. 5, p. 83-90, 2015. http://dx.doi.org/10.18607/ES33982014\%25e1\%25001

INTERNATIONAL SEED TESTING ASSOCIATION - ISTA. International Rules for Seed Testing. Zurich: ISTA, 2006. 180p.

MACHADO, C. G.; MARTINS, C. C.; SANTANA, D. G.; CRUZ, S. C. S.; OLIVEIRA, S. S. C. Adequação do teste de condutividade elétrica para sementes de Pisum sativum subsp. Arvense. Ciência Rural, Santa Maria, v. 41, n. 6, p. 988-995, 2011. http://dx.doi.org/10.1590/S0103-84782011005000062

MAGUIRE, J. D. Speed of germination aid in selection and evaluation for seedling and vigour. Crop Science, Madison, v. 2, n. 2, p. 176-177, 1962. https://doi.org/10.2135/cropsci1962.0011183X000200020033x

MASCHIETTO, R. W.; NOVEMBRE, A. D. L. C.; SILVA, W. R. Métodos de colheita e qualidade das sementes de capim colonião cultivar Mombaça. Bragantia, Campinas, v. 62, n.2, p. 291-296, 2003. http://dx.doi.org/10.1590/S0006-87052003000200015

MARCOS FILHO, J. Fisiologia de sementes de plantas cultivadas. Piracicaba: FEALQ, 2005. 495p.

MARCOS FILHO, J. Seed vigor testing: an overview of the past, present and future perspective. Scientia Agricola, Piracicaba, v. 72, n. 4, p. 363-374, 2015. https://doi.org/10.1590/0103-9016-2015-0007

MERTZ, L. M.; SEGALIN, S. R.; HUTH, C.; ROSA, T. D. A. Condutividade elétrica individual para a avaliação do potencial fisiológico de sementes de trigo. Informativo ABRATES, v. 22, n. 1, P. 35-39, 2012.

MONTAGNER, D. B.; EUCLIDES, V. P. B.; GENRO, T. C. M.; NATES, N. N. Dry matter intake by beef steers on Piatã palisadegrass (Brachiaria brizantha cv. BRS Piatã) pasture. Tropical Grasslands- Forrajes Tropicales, Cali, v. 1, n. 1, p. 106-108, 2013. http://dx.doi.org/10.17138/TGFT(1)106-108

NOGUEIRA, J. L.; SILVA, B. A.; CARVALHO, T. C.; PANOBIANCO, M. Teste de condutividade elétrica para avaliação do potencial fisiológico de sementes de aveia preta. Revista Ceres, Viçosa, v. 60, n. 6, p. 896901, 2013.

OLIVEIRA, S. S. C.; MARTINS, C. C.; CRUZ, J. S.; SILVA, J. C. Seleção de progênies de nabo-forrageiro para germinação sob altas temperaturas. Ciência Rural, Santa Maria, v. 44, p. 217-222, 2014. http://dx.doi.org/10.1590/S0103-84782014000200004

PARIZ, C. M.; FERREIRA, R. L.; DE SÁ, M. E.; ANDREOTTI, M.; CHIODEROLI, C. A.; RIBEIRO, A. P. Qualidade fisiológica de sementes de Brachiaria e avaliação da produtividade de massa seca, em diferentes sistemas de integração lavoura-pecuária sob irrigação. Pesquisa Agropecuária Tropical (Agricultural Research in the Tropics), Goiânia, v. 40, n. 3, p. 330-340, 2010. http://dx.doi.org/10.5216/pat.v40i3.6590 
PEREIRA, C. E.; OLIVEIRA, J. A.; ROSA, M. C. M.; KIKUTI, A. L. P. Armazenamento de sementes de braquiária peletizadas e tratadas com fungicida e inseticida. Ciência Rural, Santa Maria, v. 41, n. 12, p. 20602065, 2011. https://doi.org/10.1590/S0103-84782011001200004

PEREIRA, W. A.; SÁVIO, F. L.; BORÉM, A.; DIAS, D. C. F. S. Influência da disposição, número e tamanho das sementes no teste de comprimento de plântulas de soja. Revista Brasileira de Sementes, Londrina, v. 31, n. 1, p. 113-121, 2009. https://doi.org/10.1590/S0101-31222009000100013

R CORE TEAM. R: A language and Environment for statistical computing, Vienna: R Foundation for Statistical Computing, 2016.

SOARES, M. M.; CONCEIÇÃO, P. M.; DIAS, D. C. F. S.; ALVARENGA, E. M. Testes para avaliação do vigor de sementes de sorgo com ênfase à condutividade elétrica. Ciência e Agrotecnologia, Lavras, v. 34, n. 2, p. 391-397, 2010. http://dx.doi.org/10.1590/S1413-70542010000200017

STEINER, F.; OLIVEIRA, S. S. C.; MARTINS, C. C.; CRUZ, S. J. S. Comparação entre métodos para a avaliação do vigor de lotes de sementes de triticale. Ciência Rural, Santa Maria, v. 41, n. 2, p. 200-204, 2011. http://dx.doi.org/10.1590/S0103-84782011005000011

TOMAZ, C. A.; MARTINS, C. C.; SANCHES, M. F. G.; VIEIRA, R. D. Time reduction for surinam grass seed germination test. Ciência e Agrotecnologia, Lavras, v. 39, n. 5, p. 488-497, 2015. http://dx.doi.org/10.1590/S1413-70542015000500007

TUNES, L. M.; TAVARES, L. C.; BARROS, A. C. S. A. Envelhecimento acelerado como teste de vigor para sementes de arroz. Revista de Ciências Agrárias, Lisboa, v. 35, n. 1, p. 120-127, 2012.

VANZOLINI, S.; ARAKI, C. A. S.; SILVA, A. C. T. M.; NAKAGAWA, J. Teste de comprimento de plântula na avaliação da qualidade fisiológica de sementes de soja. Revista Brasileira de Sementes, Londrina, v. 29, n. 2, p. 90-96, 2007. https://doi.org/10.1590/S0101-31222007000200012 